\title{
Culture and physiological variability in Rhizoctonia solani, responsible for foliar and lesions on aerial part of soybean
}

\author{
L alan Sharma ${ }^{1 *}$, Sanjay Goswami² and D. T. Nagrale \\ ${ }^{1}$ Department of Plant Pathology, College of Agriculture, G. B. Pant University of Agriculture and Technology, Pantnagar- \\ 263145 (UK), INDIA \\ ${ }^{2}$ Department of Plant Pathology, Punjab Agriculture University, Ludhiana- 141004 , INDIA \\ ${ }^{3}$ Department of Plant Pathology and Agricultural Microbiology, Mahatma Phoole Agricultural University, Rahuri- \\ Rahuri-413722, INDIA \\ "Corresponding author. E-mail: drsharmanbaim@rediffmail.com
}

Received:F ebruary 4, 2012; Revised recei ved: J anuary 14, 2013; Accepted:F ebruary 2, 2013

\begin{abstract}
Foliar blight of soybean is one of the major fungal diseases. Rhizoctonia solani isolated from soybean growing in tarai regions of Uttarakhand. Six isolates of R. solani has been characterized on the basis of cultural and physiological nature such as colony diameter, growth, colour and sclerotia formation were recorded. Potato Dextrose Agar (PDA) was found best for growth and development. Two isolates (Lakhimpur and Pantnagar) covered the whole plates $(90 \mathrm{~mm})$ in $48 \mathrm{hrs}$. However, maximum number of sclerotia and weight was recorded on Czapek Dox agar medium. Overall radial growth supporting is recorded Corn Meal Agar Medium. Varied range of temperatures i.e. $10,15,25,30,35$ and $40^{\circ} \mathrm{C}$ was tested and found better growth of different isolates of $\mathrm{R}$. solani at $10-40^{\circ} \mathrm{C}$, with an optimum growth temperature at $30^{\circ} \mathrm{C}$. Isolates were grown on five broth media (Asthana \& Hawkers, Potato Dextrose Agar, Czapek's Dox Agar, Corn Meal Agar and Richards Agar) for fresh, dry weight and oat meal broth culture filtrates of all isolates was used in phytotoxic effects. It recorded that maximum fresh and dry weight was observed on corn meal agar medium. The maximum reduction in radical and plumule length of germinating seeds were recorded in Haldichaur isolate.
\end{abstract}

Keywords: Cultural, Foliar blight, Physiological, Phytotoxic, Rhizoctonia solani and Soybean

\section{INTRODUCTION}

Foliar/Leaf blight of soybean caused by Rhizoctonia solani Kuhn is a severe disease and causes heavy loss in soybean production (Anwar et al.,1995). Soybean [Glycine max (L.) Merril] plants are infected by the pathogen at any stage of development, which causes very rapid defoliation and frequent crop failure (Wrather et al., 2001). Fenille et al. (2002) have reported 31-60\% yield losses due to foliar blight of soybean. The symptoms of aerial blight of soybean caused by R. solani, as leaf and pod spots, leaf blight, defoliation, stem and petiole lesions, cob web like mycelium and sclerotia developed over infected leaves were described by Atkins and Lewis (1954). The R. solani produces sclerotia as survival structure which is brown to black composed of clusters of melanin encrusted, thick walled cells, rich in nutrients, formed by repeated branching from short, thick, lateral hyphae, when produced on plant parts it is difficult to separate the sclerotia from their surrounding embeded sclerotia. Temperature is more considerable parameter for their growth and development along with sclerotia production. The phytotoxicity of their metabolites make spot on the foliage become greenish to reddish brown and later turn brown to black in colour. In severe form whole leaf may be blighted. It also inhibited root elongation causing seedling root rot, yellowing and shredding of cotyledons and leaves in soybean. Therefore, integrated management of plant disease based on the laboratory studies to identify the adverse climatic conditions or photoinsensitive varieties or rotational use of chemicals to control the plant disease is considerable as R. solani have been reported to shows variation in characteristics.

\section{MATERIALS AND METHODS}

Survey and collection of sample showing blight symptoms from soybean growing areas of tarai regions mainly in Uttarakhand were done. The isolates (Rudrapur, Sitarganj, Haldichaur, Lakhimpur, Durgapalpur and Pantnagar) of R.solani, were isolated on PDA and purified through hyphal tip/single sclerotial method (Rangaswami and Mahadevan, 2004). In cultural studies; mycelial discs of $5 \mathrm{~mm}$ diameter from 3 days old cultures of each isolates were transferred into the center of sterilized different culture media and plates were incubated for 5 days at $28 \pm 1^{\circ} \mathrm{C}$. The basic cultural characteristics such as colony diameter, colour and growth pattern were studied. The colony colour was determined with help of Munsell's ISSN : 0974-9411 (Print), 2231-5209 (Online) All Rights Reserved ๑ Applied and Natural Science Foundation www.ansfoundation.org 
soil colour chart (Munsell, 1954). Based on mycelial pigmentation, the cultures were assigned in different groups as dark brownish, dark white and dirty brown. Colony growth pattern was recorded by visual observation according to growth of hyphae. Colony diameter growth rate was recorded on the five different media i.e. three synthetic media (Asthana and Hawkers, Czapek's agar and Richard's agar), one semi synthetic medium (PDA) and one natural medium (Corn Meal Agar medium) after $48 \mathrm{hrs}$ of inoculation at $28 \pm 2^{\circ} \mathrm{C}$ with the help of scale. The isolates were classified into slow; splash, fast, thin and fluffy growth. Growth was measured of the each isolate with three replications. The number, weight, colour, texture (smooth and rough) and patterns of sclerotia formed were recorded. In another physiological experiment; a total of six different temperature viz. $10,15,25,30,35$ and $40^{\circ} \mathrm{C}$ were evaluated to find out the suitable temperature level for radial growth and sclerotia formation, were incubated and observed after at 72 and $120 \mathrm{hrs}$, respectively. Each treatment was replicated thrice. A total of five broth medium viz. (Asthana \& Hawkers, Potato Dextrose Agar, Czapek's Dox Agar, Corn Meal Agar and Richards Agar) were tested for biomass (fresh and dry weight) production. $125 \mathrm{ml}$ medium was taken in flask and inoculated with $5 \mathrm{~mm}$ disc of the each isolates. Inoculated flasks in triplicates were incubated for 15 days at $28 \pm 1^{\circ} \mathrm{C}$. After incubation period mycelial mat and sclerotia were filtered through Whatman No.41 filter paper. The weight of dried mycelium along with sclerotia was recorded by subtracting the weight of filter paper from the total weight. Although, the result of biomass production was recorded after $15^{\text {th }}$ day and observed that oat meal broth medium supports biomass for all the isolates. Therefore, culture filtrate on oat meal broth medium was used phytotoxic effect on soybean variety NRC-64, for seed germination of soybean. The healthy looking seeds of soybean Cv. NRC-64 were surface sterilized with two per cent chlorex solution for one minute and kept for soaking in culture filtrate for 12 hrs. The 25 soaked seeds were taken out and placed in sterilized wetted blotter paper and kept for 3 days for seed germination. Along with sterilized distilled water soaked seeds were kept as check. Observations were recorded after $70 \mathrm{hrs}$ of incubation at $28 \pm 1^{\circ} \mathrm{C}$. Percent inhibition over control was calculated by applying the following formula (Mc kinney, 1923).

$$
\mathrm{I}=\frac{\mathrm{C}-\mathrm{T}}{\mathrm{C}} \times 100
$$

Where, $\mathrm{I}=$ Percent inhibition, $\mathrm{C}=\mathrm{radical} / \mathrm{plumule}$ length in control, $\mathrm{T}=\mathrm{radical} / \mathrm{plumule}$ length in treatment

\section{RESULTS AND DISCUSSION}

Colony diameter, growth pattern and colour showed great diversity among the all isolates. On the basis of growth pattern, the isolates were categorized into five groups: slow, splash, fast thin and fluffy. Only two isolates (Rudrapur and Sitargang) showed slow growth. Burpee et al. (1980) had grouped the growth pattern in three groups. Colony colour of all the isolates were grouped into 4 groups: dark brownish, dirty white, milky white and dirty brownish. Three isolates (Sitargang, Haldichaur and Pantnagar) showed the dirty white mycelial pigmentation. Sunder et al. (2003) had reported varied brownish pigmentation of mycelial structure. Colony diameter and growth rate were recorded after 48 hrs. Isolates were grown on different media. PDA was found best for growth and development in comparison to others. Two isolates (Lakhimpur and Pantnagar), covered the whole plates $(90 \mathrm{~mm})$ in $48 \mathrm{hrs}$ (Table 1). Singh et al. (1974) reported that PDA was found best for radial growth. The maximum number of sclerotia and weight was recorded on Czapek Dox agar medium. Tiwari and Khare (2002) reported that Czapek's Dox Agar was best for sclerotial production. Sclerotial colour grouped into two: dark brown and light brown and sclerotial formation pattern grouped in excellent, good and fair (Table 2). Sinha and Ghufran (1988) reported that more variations in the number weight and colour. The data

Table 1. Effect of culture medium on radial growth different isolates of R. solani at $28 \pm 1^{\circ} \mathrm{C}$ after 48 hrs of incubation period.

\begin{tabular}{lcccccc}
\hline \multirow{2}{*}{ I solate } & \multicolumn{3}{c}{ Media/ Radial growth (mm) } \\
\cline { 2 - 7 } & $\begin{array}{c}\text { A sthana and } \\
\text { H awkers }\end{array}$ & $\begin{array}{c}\text { Potato } \\
\text { dextrose agar }\end{array}$ & $\begin{array}{c}\text { C zapek's } \\
\text { dox agar }\end{array}$ & $\begin{array}{c}\text { Corn meal } \\
\text { agar }\end{array}$ & $\begin{array}{c}\text { Richards } \\
\text { agar }\end{array}$ & $\begin{array}{c}\text { M ean } \\
\text { Rudrapur }\end{array}$ \\
Sitargang & 37.00 & 88.00 & 81.20 & 72.00 & 55.20 & 66.68 \\
Haldichaur & 32.40 & 88.20 & 68.00 & 74.80 & 64.00 & 65.48 \\
Lakhimpur & 38.00 & 88.80 & 76.20 & 79.40 & 72.60 & 71.00 \\
Durgapalpur & 38.40 & 90.00 & 83.00 & 74.40 & 72.80 & 71.72 \\
Pantnagar & 29.80 & 85.00 & 83.20 & 78.20 & 63.80 & 67.88 \\
\hline Mean & 42.60 & 90.00 & 72.00 & 68.00 & 74.60 & 69.88 \\
\hline LSD $(\mathrm{P}=0.05)$ & $\mathrm{a}=3.61 \mathrm{~b}=3.29$ & $\mathrm{a} \times \mathrm{b}=8.07 \mathrm{CV}(\%)=9.38$ & & 67.06 \\
\hline
\end{tabular}

$\mathrm{a}=$ isolate, $\mathrm{b}=$ media, $\mathrm{a} \times \mathrm{b}=$ interaction, *mean of three replications 

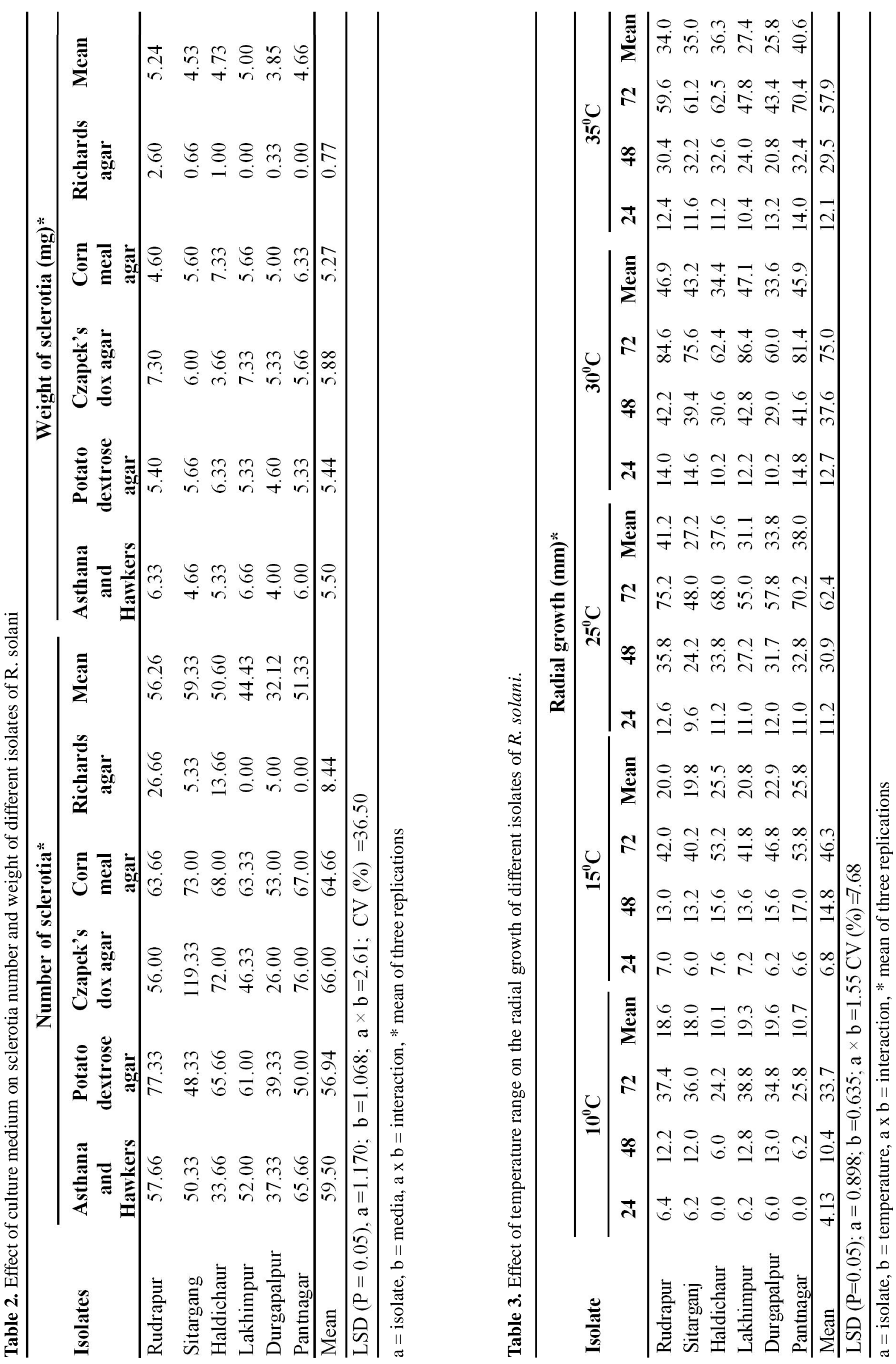
Table 4. Effect of broth culture medium on biomass (fresh weight) production.

\begin{tabular}{lcccccc}
\hline \multirow{2}{*}{ I solate } & \multicolumn{4}{c}{ Biomass (fresh weight) in gm* } \\
\cline { 2 - 6 } & $\begin{array}{c}\text { Asthana and } \\
\text { Hawkers }\end{array}$ & $\begin{array}{c}\text { Potato } \\
\text { dextrose agar }\end{array}$ & $\begin{array}{c}\text { Czapek's } \\
\text { doxagar }\end{array}$ & $\begin{array}{c}\text { Corn meal } \\
\text { agar }\end{array}$ & $\begin{array}{c}\text { Richards } \\
\text { agar }\end{array}$ & $\begin{array}{c}\text { M ean } \\
\text { Rudrapur }\end{array}$ \\
Sitarganj & 8.26 & 11.33 & 9.19 & 13.85 & 10.91 & 10.70 \\
Haldichaur & 6.53 & 12.36 & 8.60 & 9.22 & 10.66 & 9.47 \\
Lakhimpur & 8.30 & 11.60 & 8.67 & 12.84 & 7.48 & 9.78 \\
Durgapalpur & 12.52 & 17.57 & 8.36 & 18.14 & 11.54 & 13.62 \\
Pantnagar & 8.29 & 13.72 & 8.30 & 23.24 & 11.45 & 13.00 \\
\hline Mean & 6.81 & 15.87 & 7.39 & 17.60 & 9.68 & 11.40 \\
\hline LSD $(\mathrm{P}=0.05)$ & $\mathrm{a}=0.282$ & $\mathrm{~b}=0.257$ & $\mathrm{a} \times \mathrm{b}=0.630 \mathrm{CV}(\%)=3.40$ & & 15.81 & 10.28 \\
\hline
\end{tabular}

$\mathrm{a}=$ isolate, $\mathrm{b}=$ medium, $\mathrm{a} \times \mathrm{b}=$ interaction, *mean of three replication

Table 5. Effect of broth culture medium on biomass (dry weight) production.

\begin{tabular}{|c|c|c|c|c|c|c|}
\hline \multirow[b]{2}{*}{ Isolate } & \multicolumn{6}{|c|}{ Biomass (dry weight) in gm* } \\
\hline & $\begin{array}{c}\text { A sthana and } \\
\text { H awkers }\end{array}$ & $\begin{array}{c}\text { Potato } \\
\text { dextrose agar }\end{array}$ & $\begin{array}{l}\text { Czapek's } \\
\text { dox }\end{array}$ & $\begin{array}{c}\text { Corn meal } \\
\text { agar }\end{array}$ & $\begin{array}{c}\text { Richards } \\
\text { agar }\end{array}$ & M ean \\
\hline Rudrapur & 1.68 & 2.36 & 2.35 & 2.26 & 2.70 & 2.27 \\
\hline Sitarganj & 1.68 & 2.52 & 2.29 & 1.91 & 2.26 & 2.13 \\
\hline Haldichaur & 1.50 & 2.33 & 2.32 & 2.09 & 2.20 & 2.08 \\
\hline Lalkhimpur & 1.87 & 2.43 & 1.82 & 2.57 & 2.68 & 2.27 \\
\hline Durgapalpur & 1.72 & 1.66 & 2.25 & 5.87 & 2.68 & 2.23 \\
\hline Pantnagar & 1.63 & 2.19 & 1.90 & 2.65 & 2.56 & 2.18 \\
\hline Mean & 1.68 & 2.24 & 2.15 & 3.39 & 2.51 & \\
\hline
\end{tabular}

$\mathrm{a}=$ isolate, $\mathrm{b}=$ medium, $\mathrm{a} \times \mathrm{b}=$ interaction, *mean of three replications

presented in (Table 3) revealed that radial growth of different isolates of $R$. solani were significantly varied when recorded after $72 \mathrm{hrs}$ of the inoculation among themselves at different temperature levels except $40^{\circ} \mathrm{C}$, where no, radial growth was recorded. However, maximum radial growth was recorded in isolate Lakhimpur and Pantnagar, at $30^{\circ} \mathrm{C}, 86.60$ and $81.40 \mathrm{~mm}$, respectively. Radial growth and sclerotia formation varied with culture media but it was observed that oat meal supports all the isolates of R. solani. Singh et al. (1974) and Dubey and Dewivedi (1992) also observed optimum growth of R.solani at $28^{\circ} \mathrm{C}$. The minimum radial growth was recorded after 72 hrs in isolate of Haldichaur $(24.20 \mathrm{~mm})$ followed by Pantnagar $(25.80 \mathrm{~mm})$ and Sitarganj $(36.00 \mathrm{~mm})$ at $10^{\circ} \mathrm{C}$. The optimum radial growth was observed at $15^{\circ} \mathrm{C}$ and $25^{\circ} \mathrm{C}$ for all the isolates of R. solani. Further, it was observed that all the isolate of $R$. solani had excellent sclerotia formation at $30^{\circ} \mathrm{C}$. Optimum sclerotia formation was occurred at 25 and $35^{\circ} \mathrm{C}$ while minimum sclerotia were occurred at $10-15^{\circ} \mathrm{C}$. Tiwari and Khare (2002) and Grosch and Kofoet (2003) also reported that the optimum hyphal growth was measured over temperature range of 20$30^{\circ} \mathrm{C}$ with optimum at $25^{\circ} \mathrm{C}$ and sclerotic production were observed at $30-35^{\circ} \mathrm{C}$ on different media. The results are similar to those reported by Lim et al. (1987) who reported poor fungal growth at 35 and $15^{\circ} \mathrm{C}$. The results obtained in the present investigation suggest that $30^{\circ} \mathrm{C}$ temperature is the optimum for the growth and sclerotia production. The data (Tables 4 \& 5) revealed that isolates Lakhimpur and Durgapalpur gave maximum growth (fresh weight i.e. more than $13 \mathrm{gm}$ ). It was closely followed by Pantnagar isolate $(11.40 \mathrm{gm})$. Among the medium, maximum biomass (Fresh weight) was recorded on the Corn meal medium (15.81 $\mathrm{gm})$ followed by potato dextrose medium (13.74 gm) and Richard's medium (10.28 gm). However, maximumbiomass (fresh weight) was recorded in the isolate of Durgapalpur (23.24gm) and Pantnagar (17.60 gm). The minimum biomass (fresh weight) was recorded in the medium Asthana and Hawker's medium. In this Corn meal broth medium also supports the growth Rhizoctonia solani isolates. Maximum biomass (dry weight) was recorded in isolate of Rudrapur and Lakhimpur (2.27 g) followed by Durgapalpur (2.23 g), the reason is due to fluffy mycelium having more water holding capacity and during drying water evaporated and reduced dry weight. In general, among the medium, maximum biomass (dry weight) was recorded on Corn Meal (3.39 g) closely followed by Richard's medium $(2.51 \mathrm{~g})$ and potato dextrose medium 
Table 6. Effect of corn meal broth culture filtrate isolates of R. solani on soybean (variety NRC-64) seed germination.

\begin{tabular}{|c|c|c|c|c|}
\hline \multirow[b]{2}{*}{ I solates } & \multicolumn{2}{|c|}{ Germination percent* } & \multicolumn{2}{|c|}{ Seedlings } \\
\hline & Germinated & Non-germinated & $\begin{array}{c}\text { Radical } \\
\text { length }(\mathrm{cm})^{*}\end{array}$ & $\begin{array}{c}\text { Plumule } \\
\text { length }(\mathrm{cm})^{*}\end{array}$ \\
\hline Rudrapur & 68.00 & 32.00 & 3.95 & 5.18 \\
\hline Sitarganj & 72.00 & 28.00 & 2.00 & 6.20 \\
\hline Haldichaur & 10.00 & 90.00 & 1.32 & 3.60 \\
\hline Lalkhimpur & 55.32 & 54.68 & 1.99 & 4.15 \\
\hline Durgapalpur & 65.32 & 34.68 & 2.12 & 6.12 \\
\hline Pantnagar & 24.00 & 76.00 & 1.36 & 4.34 \\
\hline Check & 100.00 & 00.00 & 11.32 & 17.72 \\
\hline $\operatorname{LSD}(\mathrm{P}=0.05)$ & & & 1.58 & 1.50 \\
\hline $\mathrm{CV}(\%)$ & & & 63.48 & 33.61 \\
\hline
\end{tabular}

*Mean of three replications

$(2.24 \mathrm{~g})$. However, the maximumbiomass (dry weight, 5.87 g) was recorded in the isolate of Durgapalpur grown on Corn meal medium. The minimum biomass (dry weight) was recorded on the Asthana and Hawker's medium. The data revealed (Table 6) that the fifteen days old culture filtrate on corn meal broth of different isolate of R. solani significantly reduced the radical length and plumule length of the germinated seeds as compared to check. Verma (1973) also reported that phytotoxic metabolites produced by soybean isolate of R.solani, inhibited radical elongation, showed seedling root rot yellowing the shredding of Cotyledons and leaves. The maximum reduction in radical length was recorded in Haldichaur isolate by giving $1.32 \mathrm{~cm}$ radical length. This was closely followed by Pantnagar (1.36cm). Jain and Thapliyal (1980) observed that R.solani isolated from soybean leaf produced non-host specific toxic metabolites, capable of producing leaf symptoms, supporting the present investigation. The organism produced more phytotoxic metabolites in the medium on which it grow, which causes inhibition on seed germination and inhibition of root elongation. The next best in radical length reduction was recorded in the isolate Lakhimpur $(1.99 \mathrm{~cm})$. The maximum reduction in plumule length was recorded in Haldichaur isolate $(3.60 \mathrm{~cm})$ followed by Lakhimpur (4.15 $\mathrm{cm})$ and Pantnagar $(4.34 \mathrm{~cm})$. Similarly, Sherwood and Lindburg (1962) reported that pectinolytic and cellulytic enzymes produced by the isolate of R.solani, to be phytotoxic for seed germination

\section{Conclusion}

The genus Rhizoctonia is considered as a complex mixture of filamentous fungi, having in common the possession of a non-spored imperfect state, usually referred to as the Rhizoctonia anamorph. The Rhizoctonia anamorph is characterized by several common features present among members of the entire Rhizoctonia species complex. The phytopathological studies in the complex have represented the major contingent of contributions in the group, especially in the case of R. solani. Further, molecular characterization is needed for understanding of biology, physiology and systemic study.

\section{ACKNOWLEDGEMENTS}

The authors are thankful to Head of Department of Plant Pathology and Dean Post Graduate Studies, G.B. Pant University of Agriculture \& Technology, Pantnagar (U.S. Nagar), Uttarakhand for providing necessary facilities.

\section{REFERENCES}

Anwar, S.A., Apas, S.F., Gill, M.M., Rauf, C, A., Mahmood, S. and Bhutta, A.R. (1995). Seed borne fungi of soybean and their effect on seed germination. Pakistan J. Phytopath. 7: 184-190.

Atkins, J.G. and Lewis, W.D. (1954). Rhizoctonia aerial blight of soybean in Louisiana. Phytopathology. 44: 1.

Burpee, L.L., Sander, P.L. and Sherwood, R.T. (1980). Anastomosis group among isolates of Ceratobasidium cornigerum (Bourd) Rogerand related fungi. M ycologia 72: 689-701.

Dubey, S.C. and Dwivedi, R.P. (1992). Evaluation of fungicides against the web blight disease of groundnut. Agric. Sci. Digest., 12: 90-92.

Fenille, R. C., Souza, N. L. D. and Kuramae, E. E. (2002). Characterization of Rhizoctonia solani associated with soybean in Brazil. European J. PI. Pathol., 108 : 783-792.

Grosch, R. and Kofoet, A. (2003). Influence of temperature, pH and inoculum density on bottom rot on letuce caused by Rhizoctonia solani . Zeitschrift-fur-Pflanzenkrankheiten-undPflanzenschutzt, 110(4): 366-378.

Jain, R. K. and Thapliyal, P. N. (1980). Toxic metabolites from Rhizoctonia solani Kuhn : Production and possible role in pathogenesis. Indian J. Expt. Biol., 18: 316-318.

Lim, T. K., N.G C.C. and Chin, C.L. (1987). Etiology and control of durian foliar blight and die back caused by Rhizoctonia solani. Ann. Appl. Biol., 11: 301-307.

Mckinney, H. H. (1923). Influence of soil temperature and moisture on infection wheat seedling by Halminthosporium sativum. J. Agric. Res. 26: 195-210.

Munsell (1954) Munsell's Soil Colour Chart. 1954. Munsell colour Co. Inc. Baltimore, Maryaland, U.S.A. 
Rangaswami, G. and Mahadevan, A. (Eds) (2004). Disease of crop plants in India. Prentice-Hall of India Private Limited Publisher, New Delhi, India. pp. 507.

Sherwood, R. T. and Lindberg CG. (1962). Production of a phytotoxin by Rhizoctonia solani. Phytopathology, 52 : 586587.

Singh, R., Shukla, T.N., Dwivedi, R.P., Shukla, H.P. and Singh, P.N. (1974). Studies on the soybean blight caused by Rhizoctonia solani. Indian J. M ycol. PI. Path., 4: 101-103.

Sinha, B.B.P., and Ghufran, S.M. (1988). Physiological studies on five isolates of sheath blight of rice caused by R. solan Kuhn. J ournal of Research-Rajendra Agricultural U niversity. 6: 61-67.
Sunder, S., Singh, R. and Dodan, D.S. (2003). Standardization of inoculation methods and management of sheath blight of rice. Indian J Plant Pathol., 21: 92-96.

Tiwari, A. and Khare, M.N. (2002). Conditions inducing imperfect and perfect stages in Rhizoctonia solani causing diseases of mungbean. J. Mycol. PI. Path., 32(2): 176180.

Verma, H.S. (1973). Rhizoctonia aerial blight of soybean symptomotology, etiology and chemical control. M.Sc. Thesis, G.B.P.U.A.\&T., Pantnagar. pp. 58.

Wrather, J. A., Stienstra, W. C., and Koenning, S. R. (2001) Soybean disease loss estimates for the United States from 1996 to 1998. Can. J. Plant Pathol. 23:122-131. 